\title{
PENGARUH KEBIJAKAN PENGGUNAAN ALAT TANGKAP PUKAT TARIK (SEINE NETS) TERHADAP PENDAPATAN NELAYAN DI KABUPATEN LAMONGAN
}

\author{
Muntalim dan Mohammad Syafuani Choiruddin
}

Fakultas Perikanan Universitas Islam Lamongan

Jl. Veteran No. 53 A Lamongan

\begin{abstract}
ABSTRAKS
Pro dan kontra kebijakan yang di tetapkan oleh Kementerian Kelautan dan Perikanan tentang pelarangan penggunaan alat tangkap jenis payang pada permen no 2 memilik berbagai macam dampak yang di alami oleh masyarakat nelayan di Kabupaten Lamongan. Tujuan dilakukan penelitian ini adalah untuk mengetahui dampak dari kebijakan pelarangan penggunaan alat tangkap pukat tarik (seine nets) terhadap pendapatan nelayan di Kecamatan paciran dan Brondong, serta pengaruh dari kebijakan pelarangan penggunaan alat tangkap pukat tarik (seine nets) pada masyrakat nelayan di Kecamatan Paciran dan Brondong.

Hasil produksi alat tangkap jenis payang sebelum ada kebijakan mencapai 17 ton dan sesudah ada kebijakan hasil produksi alat tangkap jenis payang mencapai 13 ton dalam sekali aktivitas tangkap. Masyarakat nelayan melaksanakan aktivitas tangkap sebanyak 19 trip dalam satu tahun, sehingga sebelum ada kebijakan hasil produksi rata-rata alat tangkap tahunan mencapai 323 ton dengan nilai uang Rp. 2,180,250,000-, sesudah adanya kebijakan hasil tangkap tahun menurun menjadi 247 ton dengan nilai uang Rp. 2,099,500,000-, pertahun. Pengaruh kebijakan pelarangan penggunaan alat tangkap pada masyarakat nelayan yaitu pengaruh ekonomi dan pengaruh psikologi, dimana pendapatan hasil tangkap masyarakat nelayan menurun dari pada tahun sebelumnya.
\end{abstract}

Key Word : Permen No 2 KKP, Pendapatan, Pengaruh

\section{PENDAHULUAN}

Pro dan kontra penerapan pelaksanaan Permen KP Nomor: 2/PERMENKP/2015tentang larangan penggunaan alat penangkapan ikan pukat hela (trawls) dan pukat tarik (seine nets) di Wilayah pengelolaan perikanan Republik Indonesia. Masyarakat nelayan menjadikan sektor perikanan sebagai sumber penghidupan (livelyhood) merasakan dampak dari terbitnya Permen ini. Peraturan Menteri Kelautan dan Perikanan No. 2 tahun 2015 di dasari oleh penurunan Sumber Daya Ikan (SDI) yang mengancam kelestarian, sehingga diberlakukan pelarangan penggunaan alat penangkapan ikan Pukat Hela (trawls) dan Pukat Tarik (seine nets).Dapat ditegaskan bahwa bertujuan untuk kelestarian dan kemajuan sektor perikanan bukan untuk mematikan mata pencaharian masyarakat nelayan.

Direktur Jenderal Perikanan Tangkap Gellwyn Jusuf (2015) yang juga memberikan keterangan pers kepada media menyatakan bahwa larangan penggunaan alat tangkap sudah mulai diberlakukan sejak tahun 1980. Keputusan Menteri Pertanian Nomor 503/Kpts/UM/7/1980 cantrang secara tegas dilarang, kemudian di tindak lanjuti dengan dikeluarkannya Keputusan Dirjen Perikanan Nomor IK.340/DJ.10106/97 sebagai petunjuk pelaksanaan dari peraturan tersebut."Pada intinya cantrang hanya diberikan bagi kapal dibawah 5 GT dengan kekuatan mesin di bawah 15 PK". Di Kecamatan Paciran dan Brondong Kabupaten Lamongan mayoritas nelayan menggunakan alat tangkap pukat tarik atau yang dalam bahasa para nelayan setempat biasa di sebut Payang (pukat tarik seine nets). Dengan adanya kebijakan Kementerian Kelautan dan Perikanan tentang larangan penggunaan alat tangkap jenis payang, dengan landasan bahwa alat tangakap jenis payang ini dapat merusak biota yang ada dalam laut misalnya, terumbu karang, ekosistem laut dan lain-lain.

Tujuan dilakukannya penelitian ini adalah untuk mengetahui dampak pengaruh kebijakan penggunaan alat tangkap pukat tarik (seine nets) pada pendapatan nelayan yang ada di Kecamatan Paciran dan Brondong. Untuk mengetahui apakah terdapat pengaruh dari kebijakan penggunaan alat tangkap pukat tarik (seine nets) pada masyarakat nelayan di Kecamatan Paciran dan Brondong. Penelitian semoga dapat memberikan informasi kepada masyarakat nelayan di Kabupaten lamongan.

\section{MATERI DAN METODE PENELITIAN}

Waktu penelitian akan dilaksanakan pada bulan Mei sampai bulan Juni 2015. Lokasi penelitian dilakukan di Kecamatan Paciran dan Brondong. 
Metode yang digunakan dalam penelitian ini adalah metode survey dan Studi kasus.

1. Survey

Penelitian survey digunakan untuk mengumpulkan data atau informasi tentang populasi yang besar dengan menggunakan sampel yang relatif kecil. Populasi tersebut bisa berkenaan dengan orang, instansi, lembaga, organisasi dan unit-unit kemasyarakatan dan lain-lain, tetapi sumber utamanya adalah orang. Desain survey tergantung pada penggunaan jenis kuisoner. Survey memerlukan populasi yang besar jika peneliti menginginkan hasilnya mencerminkan kondisi nyata, semakin besar sample survey semakin memberikan hasil akurat.

2. Studi kasus

Studi kasus adalah eksplorasi mendalam dari sistem terikat (misalnya, kegiatan, acara, proses, atau individu) berdasarkan pengumpulan data yang luas. Studi kasus melibatkan investigasi kasus, yang dapat didefinisikan sebagai suatu entitas atau objek studi yang dibatasi, atau terpisah untuk penelitian dalam hal waktu, tempat, atau batas-batas fisik.

\section{METODE PENGAMBILAN SAMPEL}

1. Kuesioner

Adalah daftar pertanyaan yang diberikan kepada responden untuk menggali data sesuai dengan permasalahan penelitian.

2. Wawancara

Merupakan proses komunikasi yang sangat menentukan dalam proses penelitian. Dengan wawancara data yang diperoleh akan lebih mendalam, karena mampu menggali pemikiran atau pendapat secara detail.

3. Observasi

Observasi yang dilakukan oleh peneliti memperoleh hasil yang maksimal, maka perlu dilengkapi format atau pengamatan sebagai instrumen. Dalam pelaksanaan observasi, peneliti bukan hanya sekedar mencatat, tetapi juga harus mengadakan pertimbangan kemudian mengadakan penilaian ke dalam suatu skala bertingkat.

\section{HASIL DAN PEMBAHASAN \\ Hasil Produksi}

Berdasarkan data yang diperoleh dari hasil kuesioner yang telah di isi oleh pengguna alat tangkap payang di Kecamatan Paciran dan Brondong. Dari 30 jumlah responden dapat diasumsikan bahwa rata-rata hasil produksi masyarakat nelayan sebelum ada kebijakan mencapai 17 ton dalam sekali aktivitas tangkap, sesudah adanya kebijakan hasil produksi masyarakat nelayan menurun menjadi 13 ton dalam sekali aktivitas tangkap. Umumnya masyarakat nelayan di Kecamatan Paciran dan Brondong melakukan 2x aktivitas tangkap (trip) dalam satu bulan, apabila dijumlahkan selama satu tahun maka nelayan melakukan aktivitas tangkap sebanyak 24 aktivitas tangkap dalam satu tahun.

Tabel 1.Rata-rata Produksi tangkap tahunan nelayan di Kecamatan Paciran dan Brondong sebelum dan sesudah ada kebijakan.

\begin{tabular}{|c|c|c|c|}
\hline \multicolumn{4}{|c|}{ Hasil Produksi pertahun } \\
\hline Uraian & Sebelum & Sesudah & Ket \\
\hline $\begin{array}{c}\text { Hasil } \\
\text { Tangkap }\end{array}$ & 17 ton & 13 ton & $\begin{array}{c}\text { 1x laju } \\
\text { tangkap }\end{array}$ \\
\hline $\begin{array}{c}\text { Jumlah } \\
\text { Operasi }\end{array}$ & 19 & 19 & Total trip \\
\hline $\begin{array}{c}\text { Total } \\
\text { Produksi }\end{array}$ & 323 ton & 247 ton & Per tahun \\
\hline
\end{tabular}

\section{Pendapatan}

Pendapatan pada usaha penangkapan ikan adalah nilai jual dari hasil tangkapan setelah operasi tangkapan selesai. Nilai pendapatan tergantung dari berat total ikan yang tertangkap dan dijual. Berdasarkan tabel 1 jumlah hasil tangkap nelayan dalam sekali aktivitas tangkap mendapatkan hasil produksi 17 ton dengan harga jual ikan rata-rata Rp.6,750-, per/kg sebelum ada kebijakan dan 13 ton dengan harga jual ikan ratarata Rp.8,500-, per/kg, untuk mengetahu hasil tangkap pertahun dalam nominal rupiah, maka hasil tangkap dikalikan harga jual dan ditambahkan jumlah operasi pertahun. Agar lebih jelas dapat dilihat pada tabel 6 .

Tabel 2. Pendapatan rata-rata pertahun nelayan di

Kecamatan Paciran dan Brondong

\begin{tabular}{|c|c|c|}
\hline \multicolumn{3}{|c|}{ Pendapatan pertahun } \\
\hline Uraian & Sebelum & Sesudah \\
\hline $\begin{array}{c}\text { Hasil } \\
\text { tangkap }\end{array}$ & 17 ton & 13 ton \\
\hline $\begin{array}{c}\text { Harga } \\
\text { Jual }\end{array}$ & Rp.6,750-, per/kg & Rp.8,500-, per/kg \\
\hline $\begin{array}{c}\text { Jumlah } \\
\text { operasi }\end{array}$ & 19 (trip) & 19 (trip) \\
\hline $\begin{array}{l}\text { Pendapat } \\
\text { an }\end{array}$ & Rp.2,180,250,000 & Rp.2.099,500,000-, \\
\hline
\end{tabular}


Berdasarkan data tabel 6 rata-rata pendapatan nelayan pertahun mengalami penurunan, pada tahun sebelum ada kebijakan mencapai Rp.2,180,250,000-, rupiah pertahun kemudian sesudah ada kebijakan mendapatkan Rp.2,099,500,000-, rupiah.

\section{Keuntungan}

Keuntungan yang diperoleh dari total pendapatan yang diperoleh dikurangi dengan total pengeluaran. Nelayan akan menekan biaya perbekalan untuk memperoleh keuntungan yang lebih besar.

Berdasarkan wawancara yang penulis temui pada beberapa tokoh nelayan serta ABK (anak buah kapal) di Kecamatan Paciran dan Brondong, sistem pembagian hasil tangkap adalah membagi hasil keuntungan dengan jumlah ABK. Maka akan terlihat berapa pendapatan nelayan dalam sekali aktivitas tangkap.

Tabel 3. Rincian jumlah pembagian hasil

\begin{tabular}{|l|r|r|}
\hline \multicolumn{1}{|c|}{ Uraian } & \multicolumn{1}{c|}{$\begin{array}{l}\text { Jumlah } \\
\text { bagian }\end{array}$} & \multicolumn{1}{c|}{$\%$} \\
\hline Perahu & 15 bagian & 37,5 \\
\hline Alat tangkap & 5 bagian & 12,5 \\
\hline Abk (15 orang) & 15 bagian & 37,5 \\
\hline Lain-lain & 5 & 12,5 \\
\hline Total & 40 bagian & 100 \\
\hline
\end{tabular}

Pengaruh kebijakan penggunaan alat tangkap

Dengan adanya kebijakan pelarangan penggunaan alat tangkap jenis payang sangat berdampak pada tingkat perekonomian masyarakat yang ada di Kecamatan Paciran dan Brondong. Sektor perikanan adalah sumber mata pencarian paling besar. Untuk kelangsungan hidup masyarakat yang ada di Kecamatan Paciran dan Brondong hanya mengandalkan hasil dari aktivitas tangkap dan pengolahan perikanan. Namun yang bisa di perbuat oleh masyarakat nelayan yang ada di Kecamatan Paciran dan Brondong pada saat ini ketika Kementerian Kelautan dan Perikanan telah memutuskan pelarangan penggunaan alat tangkap jenis payang yang dimana alat tangkap tersebut adalah alat tangkap utama masyarakat nelayan untuk melakukan aktivitas tangkap.

Kebijakan pelarangan penggunaan alat tangkap jenis payang yang di tetapkan oleh Kementerian Kelautan dan perikanan ternyata berdampak pada pendapatan masyarakat nelayan, selain pendapatan masih ada pengaruh lain dari kebijakan ini. Hasil wawancara yang penulis temui dilapangan pada beberapa anggota Rukun Nelayan di Kecamatan Paciran dan Brondong terdapat beberapa pendapat.

Menurut Fairys (2016, anggota Rukun Nelayan) “ Peraturan yang di tetapkan oleh Kementerian Kelautan dan Perikanan sangat mempengaruhi kebutuhan ekonomi pada masyarakat juga mempengaruhi hasil produksi tahunan perikanan di Kecamatan Paciran dan Brondong".

Sedangkan menurut M.Wahid (2016, Ketua Rukun Nelayan Blimbing Kecamatan Paciran) "Kebijakan pelarangan penggunaan alat tangkap jenis payang ini mempunyai dua dampak yakni :

1. Positif

Dampak positif dari pelarangan penggunaan alat tangkap ini adalah pengaruh pada biota dan ekosistem akan berjalan dengan sangat baik di karenakan menurunya jumlah operasi nelayan, sehingga trumbu karang dapat berekosistem sebagaimana mestinya.

2. Negatif

Dampak negatif dari kebijakan penggunaan alat tangkap jenis payang adalah kerugian pada pengguna alat tangkap payang dan hasil produksi tangkap tahunan. Kerugian yang dialami oleh para pengguna alat tangkap jenis payang adalah tidak dapat digunakan lagi alat tangkap payang untuk melakukan aktivitas tangkap, selain itu biaya untuk pembuatan alat tangkap payang ini sangatlah besar namun tidak dapat mereka gunakan untuk beroperasi. Sehingga mempengaruhi hasil produksi tahunan di Kecamatan Paciran dan Brondong, yang di sebabkan oleh menurunya aktivitas tangkap masyarakat nelayan yang ada di Kecamatan Paciran dan Brondong.

Berdasarkan wawancara yang penulis temui pada beberapa pengguna alat tangkap jenis payang di Kecamatan Paciran dan Brondong, dengan adanya kebijakan pelarangan penggunaan alat tangkap payang terdapat beberapa pengaruh yaitu ekonomi dan psikologi.

\section{A. Pengaruh ekonomi}

Dengan adanya kebijakan pelarangan penggunaan alat tangkap jenis payang yang telah di tetapkan oleh Kementerian Kelautan dan perikanan pada tahun 2015 sangatlah mepengaruhi perekonomian masyarakat nelayan yang ada di Kecamatan Paciran dan Brondong. Penurunan jumlah aktivitas tangkap dari 
masyarakat nelayan sangat mempengaruhi hasil produksi tahunan maupun pendapatan masyarakat nelayan yang ada di Kecamatan Paciran dan Brondong. Berdasarkan hasil data penelitian yang penulis peroleh tingkat penurunan pendapatan hasil produksi tahunan sebelum adanya kebijakan hasil produksi tahunan mencapai 323 ton, kemudian sesudah adanya kebijakan hasil produksi tahun hanya 247 ton. Sehingga dapat di asumsikan bahwa kebijakan yang di tetapkan oleh Kementerian Kelautan dan Perikanan sangat mempengaruhi hasil produksi tahunan di Kecamatan Paciran dan Brondong, selain penurun pada hasil produksi tahunan pengaruh kebijakan tersebut juga mempengaruhi hasil pendapatan masyarakat nelayan di Kecamatan Paciran dan Brondong, berdasarkan wawancara yang penulis temui pada salah satu $\mathrm{ABK}$ pengguna alat tangkap payang, menurut M. Dwi Arifin (2016, Abk Tauhid Illahi) “ Dengan adanya pelarangan penggunaan alat tangkap jenis payang yang di tetapkan oleh pemerintah sangat mempengaruhi penghasilan masyarakat nelayan, dimana kebijakan tersebut tidak terlalu pro rakyat dan tidak memperdulikan kondisi masyarakat nelayan". Salah satu pemilik armada yang menggunakan alat tangkap jenis payang juga berpendapat, menurut Aspandi “ Kebijakan yang di tetapkan merugikan banyak nelayan yang di Kecamatan Paciran dan Brondong, sebab sumber utama untuk mencukupi kebutuhan sehari-hari hanyalah sebagai nelayan".

Apabila dilihat dari beberapa pendapat masyarakat nelayan di Kecamatan Paciran dan Brondong dapat di asumsikan bahwa kebijakan pelarangan penggunaan alat tangkap jenis payang ini sangat mempengaruhi perekonomian bagi masyarakat nelayan, disamping hanya bepenghasilan pas-pasan ESDM masyarakat nelayan di Kecamatan Paciran dan Brondong di nilai rendah. Menurut pandangan Sihabun Mubin “ ESDM nelayan di Kecamatan Paciran dan Brondong sangatlah rendah, sebab mayoritas nelayan hanya lulusan SD dan SMP", dari beberapa pendangan para masyarakat nelayan di Kecamatan Paciran dan Brondong dapat di asumsikan bahwa rata-rata nelayan hanya berpendidikan lulusan SD dan SMP saja kecil kemungkinan yang sampai jenjang akademik.

B.Pengaruh Psikologi

Dengan adanya kebijakan ini masyarakat nelayan di Kecamatan Paciran dan Brondong merasakan pengaruh lain yakini pengaruh psikologi, nampak jelas setelah pada tahun sebelum-belumnya masyarakat nelayan melaksankan aktivitas tangkap dengan berpenghasilan yang lumayan cukup untuk memenuhi kebutuhan sehari-hari namun sekarang masyarakat nelayan menjadi cemas, disamping berpendidikan rendah masyarakat nelayan yang ada di Kecamatan Paciran dan Brondong minim akan pengalaman kerja di bidang yang lainnya. Dampak psikologi yang mereka alami ialah setelah kebijakan pelarangan penggunaan alat tangkap ini di tetapkan masyarakat nelayan merasa kesulitan untuk memenuhi kebutuhan sehari-hari mereka sebab alat tangkap yang biasa mereka gunakan untuk memenuhi kebutuhan telah dilarang oleh Kementerian Kelautan dan Perikanan.

Berdasarkan wawancara yang penulis temui pada beberapa Abk di Kecamatan Paciran dan Brondong, menurut Edi (2016, Abk Putra Laut) “ setelah ditetapkan kebijakan masyarakat nelayan yang ada di Kecamatan Paciran dan Brondong saat ini hanya beraktivitas dirumah atau pengangguran yang bertambah banyak". Sedangkan menurut Aliyudin (2016, Tokoh Masyarakat Nelayan)“ Tingkat pengangguran pada saat ini semakin bertambah di karenakan banyaknya armada yang enggan melaksanakan aktivitas tangkap, para pemilik armada merasa takut apabila terkena razia". Penjelasan dari beberapa Abk ini dapat di tarik sebuah kesimpulan bahwa dampak psikologi masyarakat nelayan yang ada di Kecamatan Paciran dan Brondong adalah rasa cemas akan ketidak mampuan memenuhi kebutuhan sehari-hari.

Meskipun di Kecamatan Paciran dan Brondong memiliki beberapa pabrik pengolahan hasil tangkapan nelayan tidak serta merta membutuhkan tenaga kerja yang banyak, dengan alasan stok produksi bahan pokok pabrik juga ikut menurun sebab banyak masyarakat nelayan yang tidak melakukan aktivitas tangkap seperti tahun sebelum adanya kebijakan. Berdasarkan kejadian yang ada di lapangan yang penulis temui kondisi pelabuhan perikanan sekarang yang ada di Kecamatan Paciran dan Brondong menjadi sepi dari pada tahun sebelumnya, banyak armada berbaris rapi yang membuktikan bahwa banyak pula masyarakat nelayan yang tidak melakukan aktivitas tangkap. Kejadian ini dapat di asumsikan bahwa pengaruh kebijakan yang di tetapkan oleh 
Kementrian Kelautan dan Perikanan sangat mempengaruhi tingkat perekonomian dan psikologi masyarakat nelayan di Kecamatan Paciran dan Brondong.

\section{KESIMPULAN}

Berdasarkan hasil penelitian yang penulis lakukan di Kecamatan Paciran dan Brondong dapat di simpulkan sebagai berikut Bahwa kebijakan yang di tetapkan oleh pemerintah berdampak pada hasil hasil produksi tahunan dan pendapatan masyarakat nelayan yang ada di Kecamatan Paciran dan Brondong, dimana pendapatan nelayan menurun dari tahun sebelumnya, penadapatan nelayan sebelum ada kebijakan Rp.1,743,750-, per abk dan Rp.1,637,500-, per abk dalam sekali aktivitas tangkap.

Terdapat beberapa pengaruh dari kebijakan yang di tetapkan oleh pemerintah yakni pengaruh ekonomi dan psikologi, dimana penghasilan masyarakat nelayan menurun sehingga banyak masyarakat nelayan yang enggan melaksanakan aktivitas tangkap, sehingga tingkat pengangguran yang ada di Kecamatan Paciran dan Brondong menjadi semakin meningkat dari tahun sebelumnya.

\section{DAFTAR PUSTAKA}

Anonymous, 1993. Pendapatan nelayan yang menggunakan alat tangkap payang. Jakarta: Agromedia Pustaka.

Arikunto, 2006, Metode dan tehnik pengambilan sampel. UAIN Sunan Ampel. Jurnal Fakultas ekonomi manajeman. Malang: Gramedia.

Aliyudin, 2016. Pengaruh kebijakan penggunaan alat tangkap pukat tarik (seine nets) terhadap pendapatan nelayan di kabupaten lamongan. Skripsi UNISLA.

Edy, 2010. Dampak penggunaan alat tangkap payang. Universitas Brawijaya. Jurnal Perikanan MSP. Malang: Gramedia.

Edi, 2016. Pengaruh kebijakan penggunaan alat tangkap pukat tarik (seine nets) terhadap pendapatan nelayan di kabupaten lamongan. Skripsi UNISLA.

Fairys, 2016. Pengaruh kebijakan penggunaan alat tangkap pukat tarik (seine nets) terhadap pendapatan nelayan di kabupaten lamongan. Skripsi UNISLA.
Husnah dan Sugiyono, 2006. Jenis alat tangkap di kabupaten rembang. Fakultas Perikanan Universitas Brawijayan. Malang.

Gellwyn Jusuf, 2015. Pengaruh kebijakan pelaranggan penggunaan alat tangkap. Jakarta: Liberty.

Iriantoro, 2014. Kondisi biota dalam laut diperrairan wilayah indonesia. Jakarta: Agromedia pustaka.

M. Dwi Arifin, 2016. Pengaruh kebijakan penggunaan alat tangkap pukat tarik (seine nets) terhadap pendapatan nelayan di kabupaten lamongan. Skripsi UNISLA.

M. Hermawan, 2008. Analisis keuntungan produksi PT. DJARUM. UAIN Sunan Ampel. Jurnal Fakultas Ekonomi. Malang.

M. Wahid, 2016. Pengaruh kebijakan penggunaan alat tangkap pukat tarik (seine nets) terhadap pendapatan nelayan di kabupaten lamongan. Skripsi UNISLA.

Mardalis, 1999. Metode pengambilan sampel. Universitas Brawijaya. Jurnal Fakultas Perikanan. Malang.

Margono, 2004. Tehnik dan cara pengambilan sampel. UAIN Sunan Ampel. Jurnal Ekonomi. Malang.

Munandar, 2006, Definisi pendapatan dalam bentuk ekonomi. Jakarta: Agromedia Pustaka.

Muhtar, 2008. Definisi dan jenis alat tangkap dan cara keranya. Jurnal Litbang Fakultas Perikanan. Pasca Sarjana. Bogor.

Mulyono, 2015. Dampak penggunaan alat tangkap payang. IPB Bogor. Jurnal Fakultas Perikanan. Jakarta: Rineka cipta.

Sugiyono, 2001. Metode dan tehnik pengambilan sampel. UAIN Sunan Ampel. Jurnal Ekonomi. Malang

Subani dan Banus, 2001. Hasil produksi alat tangkap twals. Yogyakarta: Kanisius.

Sudirman, 2004. Pendapatan nelayan yang menggunakan alat tangkap payang. Jakarta: Agromedia pustaka.

Suryadie, 2004. Tehnik dan pengoprasian jenis alat tangkap. Penangkapan swadaya. Bandung: Remaja Karya.

Sukirno, 2000. Cara menghitung analisis perbandingan pendapatan nelayang jenis payang dan cantrang di kabupaten rembang. Skripsi IPB Bogor. Bandung: Sinar Baru Algensindo. 